\title{
The Constitutional Basis for Government Regulation of Con- centration of Economic Power, Monopolies and Restrictive Trade Practices: The Indian Case
}

\author{
By Yash Vyas
}

\section{Introduction}

The problem of concentration of economic power, monopolies and restrictive trade practices, i.e. the monopoly problem, arises almost as a natural corollary to the rise of big corporations in modern times. Almost all developed countries and many developing countries have been aware of the problem, and have enacted anti-monopoly laws to deal effectively with it. In India, the Monopolies and Restrictive Trade Practices Act, 1969 (hereafter: MRTP Act) was enacted.

Anti-monopoly law, as has been pointed out by some commentators, "traditionally had two central concerns. The first was political - distrust of bigness and of fewness of competitors, as well as a policy preference for diversity and opportunity for the unestablished. The second was socio-economic, especially as seen from the vantage point of the small business person and the consumer."1 Many perceived that firms having economic power, either singly or jointly, have power over the allocation and use of means of production, over the prices, quantity and nature of products in narket, over the distribution of goods, over the labour force and competing businessmen, over consumers, and over the political process, both nationally and internationally. Such firms have at their disposal certain trade practices, unrelated to efficiency, which they can use to restrain competition, to damage or destroy competitors, or to in jure the ultimate consumers.

It was felt that possession of unchallenged economic power deadens initiave, discourages thrift and depresses energy. 2 Such power can become a menace - both an industrial and a social one. "It can be an industrial menace because it creates gross inequalities against existing or putative competitors. It can be a social menace because of its control of prices." 3

1 See EM. Fox and Lawrence A. Sullivan, "Antitrust - Retrospective and Prospective: Where Are We Coming From? Where Are We Going?" 62 New York University L. Rev. (1987), p. 936 at p. 944.

2 See observations in United States v. Aluminum Co. of America, 148 F. 2d p. 416 at pp. 427-28 (2d Cir. 1945).

3 United States v. Columbia Steel Co., 334 U.S. p. 495 at pp. 535-36 per Douglas J. 
It was thus realised that the drift of economic power into relatively few hands jeopardises political liberty. 4 Firms with economic power can have the power actually to cause temporary dislocations of the industrial machinery by declining either to increase employment by further investment of resources, or to provide continued employment. They can also have the ability to mould public opinion directly, or through influence upon the press, into agreement with their own views. 5

They are even capable of influencing decision-making processes in the government. In India, large firms have become larger by using their economic power to influence the exercise of governmental regulations. 6 They have manipulated the government machinery in getting an undue share of industrial licences 7 , and in pre-empting licences 8 and institutional finances 9 with the purpose of blocking the entry of new firms into the market. The Monopolies Inquiry Commission, appointed to inquire into the extent of the monopoly problem, noted that the system of controls in the shape of industrial licensing, however necessary from other points of view, has restricted the freedom of entry into industry and so helped to produce concentration of economic power. 10

The Committee on Distribution of Income and Levels of Living, popularly known as the Mahalanobis Committee, said that, in India, "concentration of economic power in the private sector is more than could be justified on functional grounds." 11 The Monopolies Inquiry Commission, for its part, pointed out that:

4 See views of Louis B. Schwartz and others in the Report of the Attomey General's Committee to Study the Antitrust Laws 2 (U.S. 1955).

5 See E.A.G. Robinson, Monopoly, 186 (Reprint 1966). See also Corwin Edwards, Maintaining Competition, pp. 99-108 (1949); Leslie Hannah and J.A. Kay, Concentration in Modem Industry Ch. 3 (1977); Lester M. Salamon \& John J. Siegfried, "The Relationship Between Economic Structure and Political Power: The Energy Industry", in Competition in U.S. Energy Industry, p. 381 (Thomas D. Duchegneau ed. 1975); Siegfried, "Market Structure and the Effect of Political Influence", 3 Industrial Organization Review (1975), pp. 1-7; Edwards, "Conglomerate Bigness as a Source of Power", in: Business Concentration Price Policy 1955, pp. 346-47.

6 See AN. Oza, "Monopoly and Public Policy", Economic and Political Weekly 1970, p. 545.

7 See generally R.K. Hazari, Report on Industrial Planning and Licensing Policy (1967); Government of India, Report of the Industrial Licensing Policy Inquiry Committee, particularly para. 2.16 and Appendix Vol. II at pp. 1-4 (1969).

8 See generally Hazari, supra note 7.

9 See, e.g., Sarkar Commission's Report (1974); Economic and Political Weekly, p. 15 (Jan 19, 1974).

10 Government of India, Report of the Monopolies Inquiry Cornmission 8 (1965). See also Report of the Industrial Licensing Policy Inquiry Committee, supra note 7 (the working of the licensing policy had been the cause of industrial growth in the private sector being concentrated in a few large houses).

11 Govemment of India, Report of the Committee on Distribution of Income and Levels of Living 54 (1964). 
"[T]he dangers from concentration of economic power and monopolistic and restrictive trade practices are not imaginary but did exist in a large measure in the country ..."12

Enacted on the rec : nmendation of the Monopolies Inquiry Commission, the MRTP Act seeks to create an environment within which market forces can best function. 13 It is mainly concemed with the control of concentration of economic power in the hands of: (i) a large undertaking having by itself or jointly with its inter-connected undertakings, total assets of value of Rupies (Rs) 100 crores ( 1 crore $=10$ million) and (ii) a dominant undertaking having by itself, or jointly with its inter-connected undertakings, total assets of Rs 20 crores. 14 Such an undertaking has to register itself with the government 15 and it cannot without the prior approval of the government: (i) undertake substantial expansion by the issue of fresh capital, or by the installation of new machinery or equipment, or in any other manner16; (ii) establish a new undertaking which when established would become an undertaking to which the anti-concentration provisions of the Act apply17; and (iii) give effect to any scheme of merger amalgamation or take-over which would result in an undertaking to which anti-concentration provisions of the Act apply.18 For these purposes, the government may accord approval if it is satisfied that it is expedient in the public interest to do so. If the govermment is of the opinion that no such approval can be given without a further inquiry, it may refer the matter to the Monopolies and Restrictive Trade Practices Commission for inquiry and report. Upon receipt of the report of the Commission, the government may pass such an order as it thinks fit. The government is authorised by the Act to order an undertaking to divest itself of some of its outstanding interests. 19

The MRTP Act also intends to regulate monopolistic, restrictive and unfair trade practices. Monopolistic 20 and restrictive trade practices 21 such as the manipulation of prices-pricefixing, predatory pricing, resale price maintenance, discriminatory practices, withholding of output, refusal to deal, market-sharing, exclusive dealing, tie-in, and collective bidding and tendering are covered by the Act.22 Unfair trade practices such as false and misleading

12 Report of the Monopolies Inquiry Commission, supra note 10, at p. 140.

13 For the provisions of the Monopolies and Restrictive Trade Practices (MRTP) Act, 1969, see generally A.M. Chackraborti, MRTP: A Compendium (4th Ed. 1984); H.M. Jhala, Law of MRTP in India (1981); NK. Sengupta, The Monopolies and Restrictive Trade Practices Act, 1969 (1980).

14 Section 20, MRTP Act.

15 Section 26, MRTP Act.

16 Section 21, MRTP Act.

17 Section 22, MRTP Act.

18 Section 23, MRTP Act.

19 Section 27, MRTP Act.

20 Sections 2(i), $31 \& 32$, MRTP Act.

21 Sections 2(o), 33 to 41 , MRTP Act.

22 There appears to be no substantial difference between the monopolistic and restrictive trade practices, particularly fter the 1984 amendments of the MRTP Act. 
representations as to standard, quality, grade, etc. of goods are also covered by the Act. ${ }^{23}$ The Monopolies and Restrictive Trade Practices Commission is empowered to investigate and inquire into these practices, but it can make final orders only in cases of restrictive and unfair trade practicre. In cases of monopolistic trade practices the Commission has only an advisory role. If, as a result of an inquiry, the Commission finds that an undertaking is indulging in a monopolistic trade practice, it shall report its findings to the government and on the receipt of such report, the government may pass such an order as it thinks fit.

As the MRTP Act has been on the statute book for more than two decades now, several obscurities and lacunae may be noticed. It has been found to be not very effective in dealing with the monopoly problem, particularly with the concentration of economic power. Facts show that there has been a considerable increase in the assets of large business houses right through this period. The value of assets of the top 20 business houses has risen from Rs 2430.61 crores in 1969 to Rs 27166.86 crores in 1987-88.24 The value of assets of the top two houses, namely Birlas and Tatas, has increased from Rs 687 crores and Rs 711 crores respectively in 1971 , to Rs 5564.37 and 5568.56 crores respectively in 1987-88.25 The main reason for the ineffectiveness of the MRTP Act is that big business had ways of either delaying or circumventing the application of those provisions of the Act which could have put a strain on their activities.

In this paper we are not as such concemed with the specific provisions of the MRTP Act, but the focus is on the constitutional issues involved in the regulation of monopolies.

The dangers from the concentration economic power, monopolies and related phenomena have clearly been recognised in the Indian Constitution of 1950 , for in it are contained a number of provisions which have bearing on these matters. 26 This paper intends critically to examine such provisions. Section I of this paper discusses the relevant constitutional background. Section II critically examines the approach of the courts towards provisions relating to concentration of economic power, whereas section III deals with their approach towards the grant of monopoly rights to private individuals or bodies and towards trade

23 Section 36A to 36E, MRTP Act.

24 Source: Govemment of India, Report of the High Powered Expert Committee on Companies \& MRTP Acts, 251 (1978), and Answers to questions in Parliament as reported in National Herald International Weekly, New Delhi, April 27 - May 3, 1990, p. 14.

25 Source: Answers to questions in Parliament as reported in Economic and Political Weekly, Bombay, November 10, 1973, and National Herald International Weekly, New Delhi, April 27 May 3, 1990, p. 14.

26 For the provisions of the Indian Constitution see generally H.M. Seervai, Constitutional Law of India (3rd ed. Reprint 1985-1986); D.D. Basu, Commentaries on the Constitution of India (6th ed., 1973-1978); VN. Shukla, The Constitution of India (DK. Singh ed., 7th ed., reprint 1986); $M P$. Jain, Indian Constitutional Law (1978); TK. Tope, Constitutional Law of India (1982); M.CJ. Kagzi, The Const: ution of India (1984). 
combinations. This section also examines how monopoly grants and trade combinations affect the fundamental rights of other individuals. Section IV evaluates the constitutional basis for promotion or fostering of competition.

\section{The Constitutional Background}

The concepts of social and economic justice have been recognised as desirable national goals in India. The nreamble of the Indian Constitution aims at securing "Justice, social, economic and political" for all citizens. 27 The primacy of these objectives through the entire Constitution led Granville Austin to comment that:

"The Indian Constitution is first and foremost a social document. The majority of its provisions are either directly aimed at furthering the goals of the social revolution or attempt to foster this revolution by establishing the conditions necessary for its achievement. Yet, despite the permeation of the entire constitution by the aim of national renascence, the core of the commitment to the social revolution lies in Parts II and IV, in the Fundamental Rights or in the Directive Principles of State Policy. These are the conscience of the Constitution." 28

\section{A. Fundamental Rights and Directive Principles of State Policy}

\section{(1) Fundamental Rights}

The various human rights and fundamental freedoms recognised in the Universal Charter of the United Nations are enshrined in Part III of the Indian Constitution.29 The rights guaranteed under $\mathrm{t}:$. Indian constitution include the right to equality, various kinds of freedoms, the right to personal liberty, the right to freedom of religion, minority rights and the right to constitutional remedies.

27 Article 38 of the Indian Constitution gives content to this part of the preamble. It provides that: "The State shall strive to promote the welfare of the people by securing and protecting as effectively as it may a social order in which justice, social, economic and political, shall inform all the institutions of the national life."

28 Austin, The Indian Constitution: Comerstone of a Nation (1966), p. 50. This view has found the judicial approval of the Supreme Court in Minerva Mills Ltd. v. Union, All India Reporter (A.I.R.) 1980, S.C. p. 1789, see particular observations of Chandrachud C.J. and Bhagwati J. at p. 1806 \& p. 1845 respectively. Kerala v. Thomas, (1976) 2 Supreme Court Cases (S.C.C.), p. 310 (directive principles are "social conscience of the Constitution", per Fazal Ali J.).

29 See the text of Universal Declaration of Human Rights, 1948, in Human Rights (FE. Dowrick ed. 1979), pp. 139-43. 
The right to equality is dealt with in Art. 14 to 18 of the Constitution. Art. 14 guarantees to all persons - whether Indian citizen or not - equality before the law and also the equal protection of the laws. Similarly, Art. 15 prohibits discrimination by the state against any citizen on grounds solely of religion, race, caste, sex or place of birth. Equality of opportunity in matters of public employment is also guaranteed to citizens by Art. 16.

Article 19 of the Constitution deals with various kinds of freedoms. All citizens have the right (a) "to freedom of speech and expression"30; (b) "to assemble peaceably and without arms"31; (c) "to form associations or unions"32; (d) "to move freely throughout the territory of India"33; (e) to reside and settle in any part of the territory of India34; and35 (g) "to practice any profession, or to carry on any occupation, trade or business" 36 .

However, mere declarations of rights may not be of great practical value, unless there exist the will and the means to make them effective. The Indian Constitution, therefore, attempts to make these rights effective in several ways. Firstly, fundamental rights are made justiciable. The Supreme Court and the High Court of each of the states are empowered to issue directions or orders or writs including writs in the nature of habeas corpus, mandamus, prohibition, quo warranto and certiorari for the enforcement of any of the rights conferred by the provisions contained in Part III of the Constitution.37

Secondly, by virtue of Art. 13 (2) the "State" is prevented from making any law38 which takes away or abridges these fundamental rights and any law made in contravention of this mandate is, to the extent of the contravention, void.39 For this purpose the term "State" has been widely defined under Art. 12 so as to include "the Government and Parliament of India and the Govemment and the Legislature of each of the States and all other authorities

30 Article 19 (1) (a).

31 Article 19 (1) (b).

32 Article 19 (1) (c).

33 Article 19 (1) (d).

34 Article 19 (1) (e).

35 It may be noted that Article 19 (1) (f) guaranteeing right "to acquire, hold and dispose of property" and Art. 31 guaranteeing that "no person shall be deprived of his property save by authority of Law" have now been removed from Part III of the Constitution under Constitution (Forty-Fourth Amendment) Act 1978. The right to property is no longer a fundamental right. It is now only a legal right under Art. 300(A) of the Constitution.

36 Article 19 (1) (g).

37 See Arts. 32 and 226.

38 Article 13(3) defines "law" very widely so as to include an ordinance, order, bye-law, rule, regulation, notification, custom or usage having the force of law.

39 Article 13(2) provides: "The State shall not make any law which takes away or abridges the right conferred by this part and any law made in contravention of this clause shall to the extent of contravention be void." 
within the territory of India or under the control of the Govemment of India." This definition does not expressly mention the judiciary. However, it is thought that "the inclusive definition of the word 'State' does not exclude the Judiciary." 40 The fundamental rights guaranteed under the Constitution, however, are not absolute but are subject to certain limitations which have been specified in the Constitution itself. The state is not prevented from imposing reasonable restrictions on the exercise of these rights. For instance, each of the freedoms guaranteed under Art. 19 is liable to be curtailed by law to the extent mentioned in clauses (2) to (6) of that Article. Thus Art. 19 (2) enables the state to impose restrictions on the freedom of speech and expression in the interests of the sovereignty and integrity of India, friendly relations with foreign states, public order, decency, morality, or in relation to contempt of court, defamation or incitement to an offence. Similarly, freedom of assembly may be restricted by virtue of Art. 19 (3) in the interests of the sovereignty and integrity of India and public order. Art. 19 (4) permits restrictions on freedom of association in the interests of sovereignty and integrity of India or public order or moraliy. Art. 19 (5) enables the state to impose restrictions on right to freedom of movement and residence in the interests of the general public or for the protection of the interests of any scheduled tribe. By virtue of Art. 19 (6), reasonable restrictions may be imposed in the interests of the general public on the exercise of the right to freedom of trade guaranteed by Art. 19 (1) (g).

It may be mentioned that the Constitution as such does not expressly provide for imposition of reasonable restrictions on the right to equality conferred under Art. 14. This right, however, is not absolute, for the doctrine of classification has been incorporated in it by judicial decisions. 41 This reasonable classification founded on intelligible differentia and having a relationship with the object sought to be achieved is permitted under Art. 14 .

Few points in relat $n$ to imposition of restrictions on the exercise of fundamental rights must be noted. First, restrictions can be imposed only by law. Imposition of restrictions by an executive act is not permitted. Secondly, the restriction imposed must be reasonable. 42 It should not be arbitrary or of an excessive nature, beyond what is required by the interest to be protected.43 The following test laid down by Patanjali Sastri C.J. in Madras v. V.G. Row 44 has generally been accepted as correct:

40 Seervai, supra note 26, Vol. I at p. 160.

41 See, e.g., R.K. Dalmia v. Justice Tendulkar, A.I.R. 1958, S.C. p. 538; Makhan Lal v. Union (1961) 2 Supreme Court Reports, India (S.C.R.) p. 12; Charanjit Lal v. Union, A.I.R. 1951, S.C. p. 41; Chandra Kant v. Union, A.I.R. 1978, S.C. p. 314.

42 For the role of reasonable restrictions see generally TK.K. Iyer, Judicial Review of Reasonableness in Constitutional Law (1979).

43 See observations of Mahajan J. in Chintaman Rao v. M.P., A.I.R. 1951, S.C. p. 118.

44 A.I.R. 1952, S.C. p. 196. 
"The test of reasonableness, wherever prescribed, should be applied to each individual statute impugned, and no abstract standard or general pattern of reasonableness can be laid down as applicable to all cases. The nature of the right alleged to have been infringed, the underlying purpose of the restrictions imposed, the extent and urgency of the evil sought to be remedied thereby, the disproportion of the imposition, the prevailing conditions at the time, should all enter into the judicial verdict." 45

Finally, restrictions imposed on one right may affect another right, while at the same time those restrictions do not fall under the categories of restrictions enumerated as permissible vis-a-vis that other right. This may create a conflict between the state's power to impose reasonable restricti' $\mathrm{ns}$ and the individual's right. For example, Art. 19 (6) enables the government to impose reasonable restrictions on the right to freedom of trade, in the interests of the general public,whereas freedom of speech and expression cannot be restricted in terms of this article, or generally in the interests of the public for that matter. But restrictions imposed on the business activities of newspaper undertakings in the interests of the public under Art. 19 (6) may affect the right to freedom of speech and expression guaranteed under Art. 19 (1) (a). 46

The fundamental constitutional problem, therefore, is how to resolve this conflict. There is no unanimity of approach in this problematic area. Three lines of decision are discemible. The first line of decision applied the test as to what was the direct and inevitable consequence or effect of the impugned law on the fundamental right of the petitioner. This, if a legislation directly affects the growth, expansion or circulation of a newspaper, it violates the freedom of speech and expression as conferred by Art. 19 (1) (a) and it is no answer that the restrictions are justifiable under cls. (3) to (6) of Art. 19.47 The second line of decision attempted to reconcile the interests of the legislature to impose reasonable restrictions and the interests of individuals to enjoy their fundamental rights. In All India Employees Association v. Industrial Tribunal 48 and Raghubar Dayal v. Union49, the Supreme Court held that, whereas the right to form an association was only subject to the reasonable restrictions mentio: : $\mathrm{d}$ in Art. 19 (3), the business activities of the association were subject to the reasonable restrictions mentioned in Art. 19 (6). The third line of decision adopted a more balanced approach. Here the courts applied the test of direct and indirect effect of the

45

6 For detailed analysis see Yash Vyas, "Freedom of the Press and the Anti-monopoly Law: Problems of Striking a Proper Balance", 10 (1) Joumal of Media Law and Practice, London (March 1989), pp. 11-12 and pp. 18-20.

47 See, e.g., Sakal Papers (Private) Ltd. v. Union, A.I.R. 1962, S.C. p. 305; Bennett Coleman \& Co. v. Union, A.I.R. 1973, S.C. p. 106; Bennett Coleman \& Co. Ltd. v. Union, A.I.R. 1986 Bom. p. 321.

48 A.I.R. 1962, S.C. p. 171.

49 (1962) 3 S.C.R.p. 547. See also text between supra notes, pp. 115 to 117. 
imposed restrictions on other fundamental rights. If the impugned legislation, which imposes restrictions on one right, is not directly enacted in respect of any other fundamental right alleged to be violated, and the alleged violations could not be shown to be a direct and inevitable result of the operation of such legislation, the question of infringement of other rights does not arise. 50

\section{(2) Directive Principles of State Policy}

The Indian Constitution not only protects individual rights against the above enumerated types of government interference; it also directs the government to protect certain affirmative or social rights wherever possible.

Part IV of the Constitution enshrines certain directive principles of state policy. These principles confer no enforceable rights on any person and impose no enforceable obligations on the state. They have expressly been excluded from the purview of the courts by Art. 37 which reads:

"The provisions contained in this Part shall not be enforceable by any court, but principles therein laid down are nevertheless fundamental in the governance of the country and it shall be the duty of the State to apply these principles in making laws."

The most significant directives for our purposes are contained in Art. 39 of the Constitution which enjoins upon the state to prevent concentration of wealth and means of production. The relevant portion of Art. 39 provides in unambigous terms that:

"The State shall in particular direct its policy towards securing -

(b) that the ownership and control of the material resources of the community are so distributed as to best subserve the common good;

(c) that the operation of the economic system does not result in the concentration of wealth and ineans of production to the common detriment."

\section{(3) Interrelationship of Fundamental Rights and Directive Principles}

It is significant that, under Art. 13 (2), there is a negative constitutional obligation of the state not to encroach upon fundamental rights, while in Art. 37 there is a positive mandate of the Constitution commanding the state to apply the principles in the directives for

50 See, e.g., S.S. Mirajkar v. Maharastra, A.I.R. 1967, S.C. I; Express Newspapers (P) Ltd. v. Union, A.I.R. 1958, S.C. p. 578; A.K. Gopalan v. Madras, A.I.R. 1950, S.C. p. 27. 
making laws and in the governance of the country. These constitutional obligations of the state may come into conflict with each other. A law enacted to give effect to a directive principle may infringe upon fundamental rights. In that situation, the question may arise as to which must prevail. This is one of the most controversial and intensely debated issues in Indian constitutional development. 51 The attitude of the judiciary on this issue, for one, has not been consistent.

Initially, the courts took the view that the directive principles should be regarded as suosidiary to fundamental rights. In Madras v. Champakam Dorairajan52, S.R. Das C.J. in the Supreme Court said that:

"The directive principles ... which by Art. 37 are expressly made unenforceable by a Court, cannot override the provisions found in Part III which, notwithstanding other provisions, are expressly made enforceable by appropriate writs, orders and directions under Art. 32. The Chapter on Fundamental Rights is sacrosanct and not liable to be abridged by an y Legislative or Executive Act or order except to the extent provided in the appropriate article in Part III. The directive principles ... have to conform to and run as subsidiary to the Chapter on Fundamental Rights. "53

In In re Kerala Education Bill 195754, the Supreme Court reiterated that the directive principles cannot override fundamental rights. Here it was held that the directive principle about free and compulsory education in Art. 45 could not be implemented at the expense of fundamental rights guaranteed to the minorities, although it was observed that:

"Nevertheless, in determining the scope and ambit of the Fundamental Rights relied on by or on behalf of any person or body, the Court may not entirely ignore these Directive Principles of State Policy laid down in Part IV of the Constitution but should adopt the principle of harmonious construction and should attempt to give effect to both as much as possible." 55

However, Hegde J. in Chandra Bhavan v. Mysore 56 took a different view:

51 For interrelationship of directive principles and fundamental rights see generally Seervai, supra note 26 Vol. 2 a: sp. 1577-1694; S.N. Ray, Judicial Review and Fundamental Rights (1974), pp. 119-25.

52 A.I.R. 1951, S.C. p. 226.

53 Id. at p. 228. See also Hanif Qureshi v. Bihar, A.I.R. 1958, S.C. p. 731 [the directive principles cannot override the categorical restriction imposed on the legislative power of the State by Art. 13(2)].

54 A.I.R. 1958, S.C. p. 956.

55 Id. at pp. 966-67.

56 A.I.R. 1970, S.C. p. 2042. 
"It is a fallacy to think that under our Constitution there are only rights and no duties. While rights conferred under Part III are fundamental, the directives given under Part IV are fundamental in the govemance of the country. We see no conflict on the whole between the provisions contained in Part III and Part IV. They are complementary and supplementary each other. The provisions of Part IV enable the legislatures and the Government to impose various duties on the citizen."57

Chandrachud J., in Kesavananda Bharati v. Kerala (hereafter: Kesavananda)58, opined that the directive principles cannot be less significant than fundamental rights; the basic object of conferring freedoms on individuals is the ultimate achievement of the ideals underlying the directive principles.

But in Minerva Mills Ltd. v. Union (hereafter: Minerva Ltd. 1980)59 Chandrachud C.J., speaking for the majority, appears to have deviated from his above views in Kesavananda when he said that harmony and balance between fundamental rights and directive principles is an essential feature of the basic structure of the Constitution; to give primacy to one over the other is to disturb that harmony; the goals set out in directive principles have, therefore, to be achieved without the abrogation of fundamental rights. This view again accords directive principles a subservient position. 60

However, in a number of cases, the courts gave due regard to the directive principles in judging the reasonableness of restrictions imposed on fundamental rights. They tumed to the directive principles to uphold the impugned legislation not otherwise falling within the

57 Id. at p. 2050.

58 A.I.R. 1973 A.C. p. 1461 at p. 2050.

59 A.I.R. 1980 A.C. at pp. 1806-07.

60 See Mohammed Ghouse, "Constitutional Law I (Fundamental Rights)", 16 Annual Survey of Indian Law (A.S.I.L.) (1980), p. 156 at p. 217. 
saving clauses in At. 19. ${ }^{61}$ This approach found expression in the following observation of Narasimham J. in Narayanamurthy v. Commissioner of Wealth Tax62:

"[I]n considering whether the restrictions are reasonable or not, the Court must have due regard to the Directive Principles of State Policy. Hence, once it is held that the levy of wealth tax is for a public purpose, i.e. for preventing the concentration of wealth in a few hands, even periodical levy of the tax annually for that purpose, with a view to implementing the provisions of Art. 39 (c), must be held reasonable restrictions ..."63

\section{B. The Constitution and the Contradictions Inherent in the Regulation of Monopolies}

The question of the regulation of the concentration of economic power and its attendant phenomena of monopolistic, restrictive and unfair trade practices is of a complex nature and involves the balancing of a number of competing interests. Various interests which can be identified in this respect include: (i) interests of an individual in entering into any trade or business, in having freedom of growth and expansion of his business and in protecting his property, and (ii) interests of the state in having a competitive economy and orderly industrial development, in the conservation of scarce resources and foreign exchange, and in the protection of he interests of small businessmen, consumers and the public in general. Since these latter interests of the state coincide with the interests of the general public, they may be termed "public interests". These various interests often conflict, but all relevant interests must be considered in any given situation.

The Indian Constitution seeks to achieve a balance between these competing interests in various ways. Firstly, the interests of an individual are sought to be protected by guarantee-

61 See, e.g., KasturiLal v. J. \& K., W.P. Nos. 481-82 of 1979 Judgement delivered on May 19, 1980 (any executive action taken by the govemment for giving effect to a directive principle would prima facie be reasonable and in the public interest); Har Shankar v. Dy. E. T. Commissioner, A.I.R. 1975, S.C. p. 1129; Nashir War v. M.P., A.I.R. 1975, S.C. p. 360; Krishna Kumar v. J. \& K., A.I.R. 1967, S.C. p. 1368; Bombay v. F N. Balsara, A.I.R. 1951, S.C. p. 318 (in above four cases regulation of trade in liquor was upheld on the ground that it was relatable to the directive principles containes in Art. 47); Orient Weaving Mills v. Union, A.I.R. 1963, S.C. p. 98 (exemption granted to petty producers from excise duty was held valid as it was to give effect to the directives in Art. 43); Bijay Cotton Mills v. Ajmer, A.I.R. 1955, S.C. p. 33 ( a law securing living wages to laboureres was upheld as it was relatable to the directive principles in Art. 43); Hanif Qureshiv. Bihar, A.I.R. 1958, S.C. p. 73 (laws banning cow slaughter were upheld as they were passed in pursuance of the directive principle contained in Art. 48); Pathuma v. Kerala, A.I.R. 1978, S.C. p. 77 (a legislation: eradicate rural indebtendness was held valid because it gave effect to the directives in Arts. 38 and 39).

62 A.I.R. 1964 at p. 128.

63 Id. at p. 133. 
ing certain rights, particularly the fundamental rights to equality and freedom of trade and the legal right to property. In the process of enjoying these rights, some undertakings may acquire economic power to such an extent that by its abuse they may injure wider public interests. In such a situation, the Constitution permits the government to intervene and protect the interests of the public by imposing reasonable restrictions on the rights of powerful undertakings.

Secondly, although the Constitution imposes an obligation on the state to prevent the concentration of economic power, this can be done only when the concentration is to the common detriment.

Finally, although the grant of monopoly rights by the state to a private person or corporation prima facie infringes upon the fundamental rights to equality and freedom of trade of other persons, such a grant is not per se bad but only when it is unreasonable. Monopoly grants serving wider public interests are reasonable and therefore allowed. Thus, the contradiction betwe $n$ the fundamental right to trade of the individual and the interests the general public in protection against the possible harmful effects of concentration of economic power is reconciled or at least resolved by giving in each case primacy to the public interest.

\section{The Distribution of Legislative Powers and the Monopoly Problem}

By virtue of Art. 246, the Union Parliament is empowered to make laws with respect to matters enumerated in the Union List, State Legislature on matters in the State List, and both the Parliament and State Legislatures on matters described in the Concurrent List. These Lists are contained in the Seventh Schedule to the Constitution.

The framers of the Indian Constitution were well aware of the monopoly problem, for they specifically empowered both the Parliament and State Legislatures to make laws on "commercial and industrial monopolies, combines and trusts" by enumerating the subject at Entry 21 in the Concurrent List.

Although private monopolies are listed at Entry 21 in the Concurrent List, there is no bar to making laws to prevent the concentration of economic power under other entries in the Concurrent, Union or State List, for some of the entries in these lists empower the making of laws on matters such as taxation, estate duty, ceiling on agricultural land holdings, abolition of Zamindary (landlordism) etc., which have an indirect bearing on concentration of economic power. For instance, in Assistant Commissioner v. Buckingham \& Carnatic 
Co. $L t d .{ }^{64}$, the Supreme Court held that the directive principles embodied in Art. 39 (c) apply both to Parliament and State Legislatures, and that there was nothing to prevent State Legislatures from implementing that directive by enacting a law under Entry 49 of the State List. 65

In pursuance of its power under Art. 246, the Indian Parliament has enacted the MRTP Act to deal directly with the monopoly problem. 66 Many other statutes have also been passed, both by the Parliam?nt and State Legislatures, which indirectly touch upon the problem of concentration of economic power. Most such laws have been upheld by the courts. 67

\section{The Indian Constitution and the Concentration of Economic Power}

The directive principle contained in Art. 39, imposing on the state an obligation to prevent the concentration of economic power to the common detriment, is very significant in that it effects the entire economic system in India. It is worthwhile noting that the MRTP Act was passed to give effect to this directive.

However, as we have seen, the attitude of the judiciary on the question of interrelationsship between directive principles and fundamental rights has not been completely consistent. 68 Hence, to remove uncertainty and doubts, Parliament, by means of the Constitution (Twenty-fifth Amendment) Act 1971, inserted a new article, viz. 31C, into the Constitution, so as to give the directive principles in Art. 39 (b) and (c) precedence over the fundamental rights in Arts. 14, 19 and 31. The avowed purpose of Art. 31C was to save laws giving effect to directive principles in Art. 39 (b) and (c) from challenge on the grounds of infringement of fundamental rights, where such laws could not otherwise be saved by the saving clauses in ar:.cles guaranteeing those rights.

64 A.I.R. 1970, S.C. p. 169. See also L. Jagannath v. Authorised Officer, A.I.R. 1972, S.C. p. 425. The Madras Land Reforms (Fixation of Ceiling on Land) Act is covered by entry 18 of the State List read with entry 42 of the Concurrent List and as such a State Legislature is competent to enact this law in order to acquire surplus land so as to give effect to principles in Art. 39).

65 Entry 49, State List relates to "Taxes on Lands and Buildings".

66 Despite this power, none of the State Legislatures, it seems, has so far enacted any legislation dealing directly with the monopoly problem. But there may be an exception; see The Maharastra Recognition of Trade Union and Prevention of Unfair Labour Practices Act 1971.

67 See, e.g., supra notes 62 and 64 and accompanying texts. See also Bihar v. Kameshwar Singh, (1952) S.C.R. p. 889 (laws aimed at doing away with the concentration of big blocks of land in the hands of a few individuals were upheld by Mahajan J. as they sub-serve the directive principles contained in Art. 39(b) and (c); Raja Suriya Pal Singh v. UP., (1952) S.C.R. p. 1056 (the validity of the U.P. Zamindari Abolition and Land Reforns Act, 1951, was upheld).

68 See supra notes 52 to 63 and accompanying texts. 
Article 31C was furner amended by the Constitution (Forty-second Amendment) Act 1976 so as to make the application of that article more comprehensive. This amendment gave precedence to all directive principles over the fundamental rights in Arts. 14, 19 and 31. By virtue of this amendment, a law enacted for implementing any of the directive principles will remain valid even if it is inconsistent with Arts. 14, 19 and 31.69 Article 31C in its present form reads:

"Notwithstanding anything contained in Article 13, no law giving effect to the policy of the State towards securing [all or any of the principles laid down in Part IV] shall be deemed to be void on the ground that it is inconsistent with or takes away or abridges any of the rights conferred by Article 14 or Article 19 and no law containing a declaration that it is for giving effect to such policy shall be called in any court on the ground that it does not give effect to such policy." [Brackets and emphasis supplied].

It is necessary to point out here that the words in brackets above were substituted by the Forty-second Amendment in place of the words "the principles specified in clause (b) or clause (c) of Article 39". Thus, while the Twenty-fifth Amendment gave primacy only to the directive principles in Art. 39 (b) and (c), the Forty-second Amendment sought to give primacy to all directive principles over the fundamental rights in Arts. 14, 19 and 31.

The constitutional validity of the original Art. 31C, as inserted by the Twenty-fifth Amendment, came up for consideration before the Supreme Court in the celebrated case of Kesavananda. 70 In the case, a majority of seven out of thirteen judges held that Parliament has no power to amend the Constitution so as to damage or destroy its basic or essential features or its basic structure. The majority further held that the first portion, i.e. the operative part of Art. 31C, was valid, whereas the second portion (i.e. the words emphasised) vas invalid. The Court thus preserved its power of judicial review.

The vires of Art. 31C in its present form came up for consideration in Minerva Ltd. 1980.71 The majority in the Supreme Court struck down the amendment sought to be introduced by the Forty-second Amendment Act and upheld Art. 31C in its pre-Forty-second Amendment form on the ground, inter alia, that the matter was no longer res integra, because the majo-

69 Article 31, whicl zuaranteed right to property, is no longer a fundamental right. It is now only a legal right under Art. 300A of the Constitution.

70 A.I.R. 1973, S.C. p. 1461. For critical analysis of this case see Seervai, "The Fundamental Rights Case: At Cross Roads", 75 Bombay L.R. (Journal) (1973), p. 47.

71 A.I.R. 1980, S.C. p. 1789. 
rity in Kesavananda ${ }^{72}$ held that the unamended Art. $31 \mathrm{C}$ was valid except for the conclusive declaration clause, which was held to be void.73

In Minerva Mills Ltd. v. Union (hereafter: MinervaLtd. 1986)74, the Supreme Court upheld a law which gave effect to the policy of the state towards securing the ownership and control of the material resources of the community to subserve the common good, on the grounds that it came under the protective umbrella of Art. 31C.

A different view, however, was taken by the Bombay High Court in Bennett Coleman \& Co. Ltd. v. Union (hereafter: Bennett Coleman 1986)75 where it was held that even if a legislation was enacted with the object of achieving the directive principles contained in Art. 39 (c), it should not damage or destroy the basic structure of the Constitution and then and only then would the harmony between fundamental rights and the directive principles be maintained. The question before the Court was whether the MRTP Act, which was enacted to give effect to the policy of the state towards securing the principle laid down in Art. 39 (c), came ur.der the protective umbrella of Art. 31C. The Court took the view that as Art. 31C was inserted by a constitutional amendment and came into force, the protective umbrella of Art. 31C was not available to the Act on the date when it came into force. The Court in this case followed the dictum laid down by the Supreme Court, in Excel Wear v. Union76, to the effect that Art. 31C merely saves the laws enacted after the coming into force of that article.

In Rahuri Sahakari Sakhar Karkhana Ltd. v. Maharastra77, however, the same High Court took a different view when it ruled that Art. 31C covers both past and future laws relying on a dictum in Waman Rao78 to the effect that Art. 31C is designed to protect past laws also.

It is submitted that, in Bennett Coleman 198679, the Court was clearly wrong in adopting the view expressed in Excel Wear. 80 It is a well settled rule of interpretation that where

72 A.I.R. 1973, S.C. p. 1461.

73 See also Waman Rao v. Union (hereafter: Waman Rao), A.I.R. 1981, S.C. p. 271. For critical analysis of Waman Rao and Minerva 1980 see Ghouse, supra note 60, at pp. 212-20; Ghouse, "Constitutional Law I (Fundamental Rights)", 17 A.S.I.L. (1981), pp. 227-32; Seervai, supra note 26, Vol. 2 at pp. 1 j32-1667.

74 A.I.R. 1986, S.C. p. 2030.

75 A.I.R. 1986, Bom. p. 321. The decision was upheld by the Divisional Bench of the Bombay High Court, see Indian Express, Bombay, October 7, 1987, at p. 1.

76 A.I.R. 1979, S.C. p. 25.

77 A.I.R. 1987, Bom. p. 248.

78 A.I.R. 1981, S.C. p. 271.

79 A.I.R. 1986, Bom. p. 321.

80 A.I.R. 1979, S.C. p. 25. 
there are two interpretations of a provision, one that provides validity to the statute in question should be adopted. 81

Another constitutional provision which needs discussion, in the present context, is Art. 31B. By virtue of this article, any statute, regulation or provision specified in the Ninth Schedule of the Constitution is immune from challenge on the ground that such a statute etc. is inconsistent with or takes away or abridges any of the fundamental rights conferred by Part III of the Constitution.82 It is worth noting that a good number of acts and regulations specified in the Ninth Schedule are those which were enacted to give effect to the anti-concentration provisions containes in Art. 39 (b) and (c).

The constitutionality of Art. 31B was examined by the Supreme Court in Waman Rao83, where it was held that all amendments to the Constitution made before April 24, 1973 (i.e. the date on which Kesavananda84 was decided), and by which the Ninth Schedule to the Constitution was a`nended from time to time by the inclusion of various statutes and regulations therein, were valid and constitutional. Amendments made on or after April 24, 1973, to the Ninth Schedule were, however, open to challenge on the ground that they are beyond the constituent power of Parliament since they damage the basic or essential features of the Constitution or its basic structure. This was qualified by saying that if any statute or regulation included in the Ninth Schedule by a constitutional amendment made after April 24, 1973, was saved by Art. 31 A or by the unamended Art. 31C any challenge to the validity of the relevant constitutional amendment by which that statute or regulation was put in the Ninth Schedule, on the grounds that the amendment damages or destroys a basic or essential feature of Constitution or its basic structure, need not be entertained. 85

In Bennett Coleman 198686, in order to counter the challenge to the validity of ss. 21 and 22 of the MRTP Act, it was pleaded on behalf of the Union of India that the MRTP Act was introduced in the Ninth Schedule at item no 91 on August 19, 1975, and therefore was

81 See, e.g., Kedar Nath Singh v. Bihar, A.I.R. 1962.

82 Article 31B reads: "Validation of certain Acts and Regulations, without prejudice to the generality of the provisions containes in Article 31A, none of the Acts and Regulations specified in the Ninth Schedule nor any provisions thereof shall be deemed to be void, or ever to have become void, on the ground that $s=h$ Act, Regulation or provision is inconsistent with or takes away or abridges any of the rights conferred by any provisions of this Part, and notwithstanding any judgment, decree or order of any court or tribunal to the contrary, each of the said Acts and Regulations shall, subject to the power of any competent legislature to repeal or amend it, continue in force."

83 A.I.R. 1981, S.C.p. 271.

84 A.I.R. 1973, S.C. p. 1461; see text accompanying supra note 70.

85 See also Minerva 1986, A.I.R., S.C. p. 2030 (where the constitutionality of a statute included in the Ninth Schedule was upheld); text accompanying supra note 74. But see Bhim Singhji v. Union, A.I.R. 1981, S.C. p. 234.

86 A.I.R. 1986, Bom. p. 321; see text accompanying supra note 75. 
entitled to enjoy the protection of Art. 31B or the Constitution. The Bombay High Court rejected this plea on the ground that in case an enactment destroys or damages the basic structure of the Constitution, then, in spite of its being included in the Ninth Schedule, it should not oust the jurisdiction of the courts from striking down the enactment or any provisions thereof. The Court was of the opinion that freedom of the press as conferred by Art. 19 (1) (a) must be considered as a basic structure of the Constitution. Accordingly, it held that the provisions of ss. 21 and 22 of the MRTP Act were violative of Art. 19 in so far as they concern newspaper undertakings.

The Court's view that freedom of the press as guaranteed by Art. 19 (1) (a) is a basic structure of the Constitution, it is submitted, is erroneous and open to basic objections on several grounds. First, it accords freedom of the press a position higher than other fundamental rights inclu. ing the freedom of speech and expression from which the freedom of press is derived.87 This is not supported by the scheme of the Constitution. Secondly, the decision is not supporteed by any authority. Even in Kesavananda88, where the doctrine of basic structure was propounded, there was no ratio that freedom of the press, or for the matter any of the fundamental rights, were basic structures of the Constitution.89 Moreover, recently the Supreme Court has again reiterated in H.S. Srinivasa Raghavachar v. Karnataka90 that any legislation aimed at securing the directive principles contained in Art. 39 (b) and (c) does not offend the basic structure of the Constitution.

It can be seen that Bennett Coleman 198691 is the odd man (or odd case) out. But even in that case, the court did not refuse to accept the validity of Art. 31C. Hence it may be said that the non-justiciable directive principles enshrined in Art. 39 (b) and (c), which formed the basis for the enactment of the MRTP Act, and many other statutes enactet for the purpose of the control of the concentration of economic power, have come to occupy in the Constitution a place higher than the justiciable fundamental rights in Arts. 14 and 19. Any law enacted to implement or achieve the aims in the directive principles embodied in Art. 39 (b) and (c) is thus immune from an attack on the ground on contravention of rights containes in Arts. 14 and 19.

87 It may be mentioned that freedom of the press is not specifically mentioned in the Constitution but is included in the freedom of speech and expression guaranteed under Art. (19 (1) (a), see, e.g., Sakal Papers (P) Lld. v. Union, A.I.R. 1962, S.C. p. 305; Srinivasa v. Madras (1951) 1 Madras Law Journal, p. 115.

88 A.I.R. 1973, S.C. p. 1461; see text accompanying supra note 70.

89 For critical analysis of courts' approach forwards freedom of the press and the monopoly problem see generally Yash Vyas, supra note 46.

90 A.I.R. 1987, S.C. p. 1518.

91 A.I.R. 1986, Bom. p. 321. 


\section{Fundamental Rights and Monopolies}

A monopoly may arise in various ways: first, by a monopoly right conferred by the state on a private individual, or a group of individuals, to the exclusion of others; secondly, when an individual firm, in the course of its development, becomes so powerful that it has control over output and prices, and acquires the capacity to prevent entry into the market of new firms. Such a power may be acquired also by means of combination among individuals or firms.

Such monopolies are imposed by traders on the public, and may be termed as industrial monopolies. They are the primary concern of anti-monopoly laws in the modern times. Finally, a monopoly may be created by the state in its own favour or in favour of any agency or corporation owned or controlled by it, i.e. a "state monopoly".

The first two types of these monopolies, i.e. private monopolies prima facie, constitute restrictions upon the fundamental rights guaranteed by the Constitution to other persons. The third type, the state monopoly, is authorised by the Constitution itself. Article 19 (6) permits the creation of a monopoly by the state in its own favour, but state monopolies are not necessarily unchecked, and are subject to judicial control.92 A discussion of state monopoly is, however, beyond the scope of this paper.

\section{A. Monopoly Rights}

A grant of monopoly rights by the state to a private person or corporation prima facie infringes the right to freedom of trade under Art. 19 (1) (g) and the right to equality under Art. 14 of the Constitution, because such grants impose restrictions on freedom of trade of other citizens which are not in the interests of the general public, are discriminatory in nature and exclude competition.

In certain circumstances, a monopoly grant may also infringe other fundamental rights. For instance, a monopolistic hold over the press may impose restrictions on the freedom of speech and expression of other citizens conferred by Art. 19 (1) (a).93 Hence monopoly rights conferred by the state on a private person in pursuance of a law or a bye-law, or by means of an order, instruction, agreement or lease, may impose unreasonable restrictions on

92 See Yash Vyas, "The Constitutional and Public Law Control of Monopolies and Restrictive Trade Practices in Public Sector Undertakings: An Indian Approach", unpublished manuscript; R.V. Pillai, "State Monopoly and Citizen", in Some Problems of Monopoly and Company Law ( $V K$. Agarwal ed. 1972), p. 105.

93 See views of Mathew J. in Bennett Coleman \& Co. v. Union (1972), 2 S.C.C. p. 788. See also Govemment of India, Monopolies Inquiry Commission Report (1965), p. 186. 
the fundamental rights guaranteed under the Constitution and may therefore be declared invalid by the courts.

But it cannot be said that such grants are unreasonable in all circumstances. They may be justified if the basis on which competition is excluded, or the restrictions imposed, is reasonable. We shall now discuss, with the help of decided cases, the circumstances in which such grants may be unreasonable, as also the circumstances in which they may be reasonable and thus can be tolerated.

\section{Unreasonable Monopoly Grants}

A bye-law framed by the Municipal Board of Kairana provided that no person could establish a market or place for wholesale transactions in vegetables, except with the permission of the Board. No bye-law was framed to authorise the Board to issue licences for this purpose. Another bye-law framed by the Board comtemplated the grant of a monopoly to a contractor to deal in wholesale transactions at the place fixed as a market. Acting upon that provisions, the Board granted a monopoly to a private person.

The result of all these moves, however, was that the Board put itself out of its power to grant a licence to any other person to carry on wholesale business in vegetables either at a fixed market place or at any other place within the municipal limits of Kairana. The byelaws were impugned in Rashid Ahmed v. Municipal Board 94 as infringing Art. 19 (1) (g). The Supreme Court held that the restrictions imposed by the bye-laws were not reasonable as contemplated by clause (6) of Art. 19. Accordingly, they were declared void under Art. 13 (2) of the Constitution.

In a number of cases, monopoly rights conferred on co-operative societies were challenged as violative of Art. 14 and/or Art. 19 (1) (g). In Mannalal v. Assam95, the petitioner's applications for a licence to deal in food-grains were refused on the ground that the state govemment had decided to introduce a right of monopoly in favour of co-operative societies and, therefore, no licences could be granted to dealers other than co-operative societies. This was impugned as infringing Art. 14 and Art. 19 (1) (g). An attempt was made on behalf of the state to justify the monopoly by arguing, inter alia, that clause 5 (e) of the Assam Food Grains (Licencing \& Control) Order enabled the licensing authority to prefer a

94 A.I.R. 1950, S.C. p. 163. A similar decision is to be found in Mohammed Yasin v. Town Area Committee, A.I.R. 1952, S.C. p. 115.

95 A.I.R. 1962, S.C. p. 386. For a minority opinion see infra note 109. See also District Collector v. Ibrahim \& Co., A.I.R. 1966, A.P. p. 310; Lal Chand v. District Food \& Supplies Controller, A.I.R. 1965, Punj. p. 410; Pratap R. \& T. Factory v. Punjab, A.I.R. 1966, Punj. p. 16; Harudananda v. Revenue Divisional Commissioner, A.I.R. 1979, Or. p. 13. 
co-operative society in granting a licence. The majority in the Supreme Court said that clause 5 (e) of the Order does not violate the fundamental rights conferred by the Constitution, but that the instructions by the govemment intended to create a monopoly in favour of co-operative societies amounted to discrimination and were for a purpose not contemplated by clause 5 (e). It was, therefore, held that the govemment order was bad as it violated the rights of the petitioner guaranteed under Arts. 14 and 19 (1) (g) of the Constitution.

Gobind Ram v. State 96 was concerned with the instructions issued by the State Bank and the Registrar of Co-operative Societies in connection with the granting of loans to agriculturists for the purchase of diesel engines. The said instructions stated that the loanees were to purchase engines of particular makes only and not others, and that the loans were to be granted not in cash but in kind, i.e. engines. The Punjab High court was of the view that the effect of the directions was to create a monopoly in favour of certain manufacturers, and that this was against the principle of freedom of trade enshrined in Art. 19 of the Constitution.

In Rajasthan v. Mohan Lal Vyas 97 , the respondent and the former Princely State of Jodhpur entered into two agreements. Under both the agreements, the respondent was given monopoly rights by the State to ply buses on the routes mentioned in the agreements, in return for certain sums of money. Subsequently, India achieved independence, the State of Jodhpur merged with the State of Rajasthan and the Constitution came into force. The State of Rajasthan issued a demand notice for the amount payable to it subsequent to the coming into force of the Constitution. The respondent opposed the payment on the ground that, on the Constitution's r.ming into force, the monopoly contracts between him and the State became void and were unenforceable.

The lower court and the Rajasthan High Court 98 accepted the contention of the respondent, and declared that the monopoly agreement became void after the coming into force of the Constitution. The decision was upheld by the Supreme Court. In the course of judgment, it observed that:

"[ ] $f$ the State conferred any monopoly right on a citizen, it would be indefensible and impermissible and would be an infraction of the inviolable provisions of the Constitution."99

96 A.I.R. 1972, P. \& H. p. 471.

97 A.I.R. 1971, S.C. p. 2068. See also H.R.G. Industries v. Rajasthan, A.I.R. 1964, Raj. p. 205 (Monopoly contract executed on a pre-constitution date is hit by Art. 19 (1) (g) as that article does not favour creation of monopoly rights for the benefit of a person or body of persons).

98 See (1966) Indian Law Reports (I.L.R.) 16, Raj. p. 483.

99 A.I.R. 1971, S.C. p. 2068 at p. 2069. 
The decision is open to criticism on several grounds. First, the facts of this case are peculiar, as the pers $n$ to whom monopoly rights were granted had challenged the grant in order to avoid payments under the agreements. A vague contention was raised on his behalf, that the impugned monopoly contracts became void and unenforceable on the Constitution's coming into force. The Court seems to have accepted this contention. It held in very general terms that the granting of monopoly rights violates the provisions of the Constitution. In passing, of course, it said that "after the Constitution came into force, every citizen under Art. 19 (1) (g) of the Constitution has rights to ply buses and trucks on the road". 100

It is unfortunate that such an important issue was decided by the Court in such a superficial way. It is difficult to imagine any provision of the Constitution, except those relating to fundamental rights, under which grants of monopoly rights could be challenged. It was not open to the respondent to plead infringement of his fundamental rights, as his rights were more than protected. He was granted an absolute freedom to establish a monopoly in his favour. It may be argued that the impugned agreements might have infringed the rights of persons not parties to the agreements, but can a law or an agreement be simply struck down on the ground that it is likely to encroach upon the fundamental rights of some persons when neither the person whose rights are likely to be so affected nor anybody else claiming public interest 101 has approached the Court for relief?

Secondly, a bald proposition was made by the Court that "a monopoly right cannot be conferred on a citizen under the Constitution, nor can it be justified under the Constitution".102 This, in other words, means that conferring of monopoly rights is per se bad, which seems to be a very wide proposition as monopoly grants, in certain situations, may be justified as reasonable. 103

100 Id.

101 It may be mentioned that the courts have lately shown much flexibility and liberty of approach as regards locus standi, and have allowed petitions even by strangers to the proceedings, claiming public interest but having substantial and genuine interest in the subject matter. Under the public interest litigation, an unlawful administrative action is challenged by one who may not qualify under the traditional rule of standing. See, e.g., Sheela Barse v. Maharastra, A.I.R. 1983, S.C. p. 378; S.P. Gupta v. President of India, A.I.R. 1982, S.C. p. 149; People's Union for Democratic Rights v. Union, A.I.R. 1982, S.C. p. 1473; Sanjit Roy v. Jahasthan, A.I.R. 1983, S.C. p. 328; The Fertilizer Corp. Kamgar Union v. Union, A.I.R. 1981, S.C. p. 344. But see Sachidanand Pandey v. West Bengal, A.I.R. 1987, S.C. p. 1109 (there is a necessity to lay down guidelines for entertaining public interest petitions). See also M.P. Jain and SN. Jain, Principles of Administrative Law (1986), pp. 407-503; S.P. Sathe, Administrative Law (1984), pp. 249-361. However, when the case under discussion was decided, the rules of standing were still narrow.

102 A I.R. 1971, S.C. p. 2068 at p. 2069.

103 See infra notes 106-114 and accompanying texts. 
Whereas in the above case the monopoly rights were conferred by means of agreements, in Surendra Chandra v. Tripura104 they were granted by means of a lease. A private trader in umbrella sticks was given a monopoly-cum-royalty lease to fell bamboo for umbrella sticks from the forests in Tripura. The petitioner was also a trader in umbrella sticks, who was earlier given a licence for the the extraction of umbrella sticks for a number of years. He challenged the lease as offending Arts. 19 (1) (g) and 14 of the Constitution. He contended, inter alia, that the effect of such rights was that he could not any longer get a permit, and that for his requirements he was left at the mercy of the monopoly holder. In that situation, the monopoly holder could insist on payment of a consideration over and above the royalty he had paid to the government. The result, it was argued, would be that the price of umbrella sticks would go up, and the general public would suffer. The restriction, therefore, was not a restriction in the interests of the general public. Accepting the contention as valid, the Tripura High Court held that the lease offended Arts. 19 (1) (g) and 14.

This decision, it is submitted, suggests that if a monopoly is likely to enhance prices, it is not in the interests cit the general public.

\section{Reasonable Monopoly Grants}

It cannot be said that the creation of monopoly rights has been considered bad in all circumstances. The courts have recognised a right in the state to create a monopoly where it is essential; as a counter-vailing power 105 , for the protection of consumers, for the steady supply of raw material to industries, where major economic policy issues are involved, or in trades which are related to commodities essential for the national economy or inherently dangerous.

Tika Ramji v. U.P.106 raised the question whether a notification under the U.P. Sugarcane (Regulation of Supply \& Purchase) Act 1953 violated Art. 19 (1) (g). The notification provided that where not less than 75 per cent of the sugarcane growers of the area of operation of a Sugarcane Grower's Co-operative Society were members of the Society, the occupier of the factory for which the area was assigned was not to purchase, or enter into an

104 A I.R. 1963, Tri. p. 14.

105 The American economist $J K$. Galbraith propounded the theory of countervailing power. He advances two main arguments. First, in modem industries the force compelling sellers to supply consumer's wants and to hold prices near cost is not the interseller competition, but countervailing power exercised by strong buyers. Second, a systematic propensity for power on the buyer's side is said to emerge whenever power exists on the seller's side, see Galbraith, American Capitalism: The Concept of Countervailing Power (1963), at pp. 25 \& 122-48; F.M. Scherer, Industrial Market Structure and Economic Performance (1970), Ch. 9, especially at p. 241.

106 A I.R. 1956, S.C. p. 676. 
agreement for the purchase of, cane grown by a sugarcane grower except through such a co-operative society. The object of the notification was to eliminate the unhealthy competition between the cane growers on the one hand, and to prevent malpractices indulged in by the operators of factories on the other hand. The Supreme Court held that the restrictions imposed under the notification were reasonable, as they were designed for safeguarding the interests of the large majority of the sugarcane growers in the area and worked for the greatest good of the great number. The Court upheld the monopoly grant as being in the public interests. A monopoly, therefore, was permitted so as to create a countervailing power against the monopoly power of the factory owners. 107

In Sarkari Sasta Anaj Vikreta Sangh v. M.P.108, an order conferring exclusive rights on consumer co-operative societies for the distribution of "rations" was impugned under Art. 14 of the Constitution as being discriminatory. The Supreme Court ruled that the preference shown to co-operative societies did not create a monopoly in their favour and was not discriminatory. There was a reasonable classification and a nexus with the object intended to be achieved, which was a fair and assured supply of rations to the consumer. Exclusive rights were thus upheld for the protection of the consumers. 109

In Brij Bhusan v. J. \& J.110, the State Govemment's orders guaranteeing the supply of crude oleo resin, a forest product, to three enterpreneurs for the purpose of feeding the factories to be set up by them in the State were upheld by the Supreme Court. The Court took the view that no monopoly was created by the orders. Again, conferment of exclusive rights was permitted, but this time for the steady supply of raw material to industries.

In Glass Chatons I. \& V. Association v Union 111, the Govemment issued an order under the Import and Exprt (Control) Act, prohibiting the import of glass chatons except under a licence. Licence was issued in favour of the State Trading Corporation for the import of glass chatons under para. $6(\mathrm{~h})$ of the Order, which provided that licence may be refused of

107 See also Foremost Dairies Ltd.v. Rajasthan, A I.R. 1986, Raj. p. 116 (exclusive rights conferred on Co-operative Dairy Federation to export milk outside the State was held valid and not violative of Arts. 14 and 19); Surinder Singh v. Haryana, A I.R. 1986, P. \& H. p. 222 (a notification stipulating that all unskilled word up to any value and skilled work up to a certain limit should be allotted to a co-operative society was held not to be violative of Art. 14. It was also held that the notification did not create a monopoly in favour of societies).

108 A I.R. 1981. S.C. p. 2030.

109 See also Mannalal v. Assam, A I.R. 1962, S.C. p. 386 (the minority opinion stated that a preference shown to co-operative societies, even if it resulted in other dealers being prevented altogether from dealing in food grains, would be a reasonable restriction on the latter's right to trade, for that was necessary to secure the people a supply of food grains at reasonable prices and in adequate quantities). For the majority opinion see text accompanying supra note 95).

110 A I.R. 1986, S.C. p. 1003.

111 (1962) 1 S.C.R. p. 826. 
the licensing authority decided to canalise import. The petitioner pleaded before the Supreme Court to direct the respondent not to create monopoly in favour of the State Trading Corporation. As the period of the import permit had already expired, the Court refused to give any direction. However, it seems that the Court really dealt with this matter when it decided that para. 6 (h) of the Order was valid. The Court arrived at this decision by observing that such canalisation is not per se an unreasonable restriction, and that it would be presumed to be in the public interest unless the contrary was clearly shown.112 Thus, the refusal of the opportunity to persons outside a selected agency to enter into trades having impact on national economic policies, such as that of import and export, cannot be said to be unreasonable.

In M.B. Cotton Association Ltd. v. Union113, an Order banning all contracts and options in cotton except those permitted by the Textile Commissioner was impugned on the grounds, inter alia, that the petitioner had been prevented from carrying on the business of hedge contracts and was discriminated against, as another association was allowed to carry on the business and was given a virtual monopoly. The Supreme Court ruled that the Order was valid and not offending Arts. 19 (1) (g) and 14. The Court opined that, cotton being a commodity essential to the life of the community, it was reasonable to have restrictions which might extend to total prohibition, and that hedging required experience and stability; also it so vitally affected the welfare of a large section of the people as well as the country's economic stability in world markets, that it could not be lightly entrusted to inexperienced hands.

Cooverjee v. Excise Commissioner 114 was concerned with an inherently dangerous trade, i.e. trade in intoxicating liquor. Here a state law conferred discretion on the Excise Commissioner to restrict the number of licences for liquor shops, and to issue them by auction to the highest bidder. The provision was challenged on the ground, inter alia, that it created a monopoly in the liquor trade in favour of a few persons. The Supreme Court rejected the conter in on the ground that it suffered from a fallacy. In the opinion of the Court, when the contract was thrown open to public auction, it could not be said that there was exclusion of competition and thereby a monopoly was created. The Court further opined that there is no right inhering in a citizen to sell intoxicating liquors. As it is a business fraught with danger to the community, it may be entirely prohibited, or be permitted under such conditions as will limit to the utmost its evils.

112 See also Daya v. Jt. Chief Controller of Imports and Exports, A I.R. 1962, S.C. p. 1796; Daruka \& Co. v. Union, A I.R. 1973, S.C. p. 2713; Sivasajan v. Union, A I.R. 1959, S.C. p. 556.

113 A I.R. 1954, S.C. p. 634.

114 A I.R. 1954, S.C. p. 220. See also Orissa v. Harinarayan, A I.R. 1972, S.C. p. 1816; Rajkishore Das v. Orissa, A I.R. 1986, Or. p. 222. 


\section{B. Trade Combinations}

Article 19 (1) (c) of the Constitution confers on every citizen a fundamental right to form an association. This right, like other rights, is not unrestrained. Clause (4) of Art. 19 empowers the state to impose reasonable restrictions on the exercise of the freedom of association in the interests of public order and morality.

Trade combinations in many cases are formed with the object of perpetuating existing monopolies, or for acquiring monopolistic positions by means of avoiding competition. The question may therefore arise, whether the freedom to form associations or combinations carries with it the concomitant right that such associations should always and in every case be allowed to achieve the objects for which they were formed, even where such objects conflict with the public interest. Such a question in fact arose in several cases.

In Raghubar Dayal v. Union115, traders of certain commodities combined together to form an association. The function of this association was to regulate forward transactions entered into between the mi.nbers of the association, and to declare rates at which contracts were to be settled. Under the provisions of the Forward Contracts (Regulation) Act 1952, certain restrictions were imposed on the association. The restrictions were impugned on the ground that if the object of an association was lawful, no restrictions could be placed upon it except in the interests of public order and morality as provided by Art. 19 (4), that the Constitution has guaranteed the freedom to form an association including one for regulating forward trading, and that the government had taken without justification the right to determine the rules and bye-laws under which the association could function.

The Supreme Court rejected these contentions, relying on its earlier decision in All Indian Bank Employees Association v. Industrial Tribunal116, where it was said that:

"If an association were formed for the purpose of carrying on business, the right to form it would be guaranteed by sub-cl. (c) of $\mathrm{Cl}$. (1) of Art. 19 subject to any law restricting that right conforming to $\mathrm{Cl}$. (4) of Art. 19. As regards its business activities, however, and the achievement of the objects for which it was brought into existence, its rights would be those guaranteed by sub-cl. (g) of $\mathrm{Cl}$. (1) of Art. 19 subject to any relevant law on the matter conforming to $\mathrm{Cl}$. (6) of Art. 19 ..."117

The Constitution thus authorises restrictions on the business activities of trade combinations or associations. Any combination of traders formed with the object of prevention,

115 (1962) 3 S.C.R. p. 547.

116 A I.R. 1962, S.C. p. 171.

117 Id. at p. 180. 
distortion or limitation of competition, or building up of monopoly power, may be regulated in the interests of the general public under Art. 19 (6) of the Constitution.

\section{Promotion of Competition}

One of the main objectives of the anti-monopoly policy is the promotion of competition. Certain industries or markets may be plagued by the lack of competition. In such markets, a few firms or combinations of firms may have monopoly power, i.e. the power to regulate output, prices or the entry of new firms into the market. In that situation, government interference may become imperative to induce competition into these markets. The question may then arise as to whether the government's action for fostering competition could be challenged as an infringement of fundamental rights of persons or firms affected by the interference.

Such a challenge w: $\mathrm{s}$ made in Harman Singh v. Regional Transport Authority 118 . Here the owners of big taxis in Calcutta, who alone had been allowed under a rule to ply taxis, protested when the rule was amended and small taxis on lower tariffs rates were allowed to ply. They claimed that they would go out of business as a result of this and that it violated their fundamental rights under Arts. 14 and 19 (1) (g) of the Constitution. In other words, they claimed that they had been given a monopoly under the existing rule, and that the rule should not be amended so as to take away this monopoly right.

The Supreme Court rejected the argument and said that:

"This article [Art. 19 (1) (g)] does not guarantee a monopoly to a particular individual or association to carry on any occupation and if other persons are also allowed the right to carry on the same occupation and an element of competition is introduced, that does not, in absence of bad faith on the part of authorities, amount to a violation of the fundamental right under Article 19 (1) (g) of the Constitution."119

The qualification as to bad faith is unwarranted and unnecessary in the situation. The question of bad faith, it is submitted, is irrelevant where the government's action is directed against a monopoly situation. It is well settled that the question of malafide does not arise in cases where the action is otherwise legal.120

118 A I.R. 1954, S.C. p. 190. See also Peoples Bus Service v. State, A I.R. 1956, Pepsu 3; Vasudeo v. Nanalal, Civil First Appeal No. 37 of 1953 decided on 29th January, 1958 (Rajasthan High Court).

119 A I.R. 1954, S.C. p. 192.

120 See, e.g., Bradford v. Pickles [1895] Appeal Cases (England) 587, HL (a bad motive cannot make wrongful an act otherwise legal). Affinned in Allen v. Flood, [1898] A.C. 1. 
The Supreme Cou. again reiterated in Hansraj v. U.P. ${ }^{121}$ that Art. 19 (1) (g) is not intended to confer a right to monopolise. It explained the scope of Art. 19 (1) (g) in the following words:

"No right is guaranteed to any private party by Article 19 of the Constitution of carrying on trade and business without competition from other eligible persons ... It is an enabling provision and does not confer a right on those already ... carrying on any occupation, trade or business to exclude and debar fresh eligible entrants ... from carrying on that occupation, trade or business. The said provision is not intended to make any profession, business or trade the exclusive preserve of a few persons." 122

In Nagar Rice \& Flour Mills v. N.T.G. Bros.123, the Director of Food and Civil Supplies made an order to shift the appellants' rice mill to a new location in the vicinity of the respondents' rice mill because of the construction of a hydro-electric project. The respondents opposed the order on the ground that their business was likely to be adversely affected. The Supreme Court ruled that a competitor in business cannot seek to prevent others from exercising their right to carry on business even if it adversely affects their trade or business.

At times, the courts have supported government actions aimed at providing special treatment to weak competitors, so as to protect them from unfair competition from powerful competitors. For example, in Orient Weaving Mills $(P)$ Ltd. v. Union 124, the government, by means of notifications, exempted a powerloom weavers' co-operative society from the payment of excise duty. The petitioners, a rival big company producing similar goods, impugned the notifications on the ground that they violated their rights under Arts. 14 and 19 (1) (g). The Supreme Court rejected the contention and pointed out that the exemption was meant primarily for the protection of petty producers from unreasonable competition by big producers like the petitioners company.

The approach of the courts in the above cases is very significant in that it provides a constitutional basis for the maintenance, fostering and promotion of competition in order to break any existing or potential monopolistic hold over the industries.

121 A I.R. 1975, S.C. p. 389.

122 Id. at p. 393.

123 A I.R. 1970, S.C. p. 246.

124 A I.R. 1963, S.C. p. 98. But see Bennett Coleman v. Union, A I.R. 1973, S.C. p. 106 (an attempt to induce competitic by giving preferential allowance to small newspapers was considered unconstitutional because it infringed the fundamental right to freedom of the press); Sakal Papers ( $P$ ) Ltd.v. Union, A I.R. 1962, S.C. p. 305 (an attempt to prevent unfair competition by introducing a price-page schedule for newspapers was held invalid because it infringed upon the freedom of the press). 


\section{Conclusions}

It can be seen that the Indian Constitution provides for broad bases to deal with the monopoly problem. The "rective principles contained in Art. 39 (b) and (c) unequivocally en join upon the state to prevent any undue concentration of wealth and means of production in private hands. At times, laws enacted to give effect to these directives may infringe fundamental rights guaranteed under the Constitution, and therefore are likely to be struck down by the courts as being unconstitutional. Article 31C was inserted into the Constitution to deal with such situations. By virtue of Art. 31C, any law enacted to give effect to Art. 39 (b) and (c) cannot be challenged on the ground that it infringes fundamental rights to equality and the various freedoms. The courts have upheld the validity of this Article and have, in general, taken the position that, in the case of a direct conflict between the fundamental rights and the provisions of a law implementing directive principles in Art. 39 (b) and (c), the latter should prevail. It would follow that the non-justiciable directives to prevent the concentration of economic power, have come to occupy in the Constitution a place higher than the justiciable fundamental rights to equality and the various freedoms. Also, the Constitution does not in all cases permit the conferring of monopoly rights on private individuals or groups of individuals. Monopoly grants are prima facie unconstitutional, because such grants are discriminatory in nature and impose restrictions on the freedom of trade and other rights of other persons.

However, a grant of monopoly rights may be sustained if it is reasonable. The Indian courts have upheld such grants for the protection of consumers, for the steady supply of raw material to industries, in the interests of major economic policy considerations, as a countervailing power, and in trades which were related to commodities essential for the national economy or inherently dangerous, because such grants were reasonable and/or in the interests of the general public. The Indian Constitution also permits restrictions in anticompetitive activities of individual undertakings or trade associations. The traders have a fundamental right to form associations, but the courts have opined that this does not carry with it the right to combine to carry on anti-competitive activities.

In many cases, the courts have upheld govemmental measures to promote competition in markets where there was not enough competition. They have thwarted attempts on the part of monopolists to oppose such governmental measures on the ground of infringement of their rights to rade and equality. The courts in such cases have invariably taken the view that the Constitution does not guarantee to any private party the right of "carrying on of trade or business withouth competition from other eligible persons."

It may be seen that the Indian Constitution not only provides for the control and regulation of the concentration of economic power, monopolies and restrictive trade practices, but also 
authorises positive and purposeful steps to create competitive market conditions which may be necessary to protect the marketplace from abuse by monopolists.

A notable feature of the Indian approach to the monopoly problem is that in cases of concentration of economic power, monopoly grants and anti-competitive activities, the Constitution provides for a "rule of reason" approach. 


\title{
The Constitutional Basis for Government Regulation of Concentration of Economic Power, Monopolies and Restrictive Trade Practices: The Indian Case
}

\author{
By Yash Vyas
}

The article focuses on the constitutional issues involved in the regulation of concentration of economic power, monopolies and related phenomena of anti-competitive trade practices. The dangers from the monopoly problem have clearly been recognised in the Indian Constitution in a number of provisions. The paper critically examines such provisions as well as the Indian Constitution's attempts at achieving the balance between various interests involved in the regulation of concentration of economic power, etc. The article attempts to establish, with the help of the decided cases, that the non-justiciable directive principle of the state policy contained in the Indian Constitution, directing the state to prevent concentration of economic power to the common detriment, has come to occupy in the Constitution a place higher than the justiciable fundamental rights to equality and various freedoms, including the freedom of trade. It is also attempted to establish that the conferment of monopoly rights by the state on a private individual or corporations is prima facie invalid, but such grants may be justified if the basis on which competition is excluded is reasonable. It has been argued that although the Constitution confers freedoms of association and trade, it permits restrictions on the anticompetitive activities of trade associations and authorises positive and purposeful steps to create competitive market conditions.

\section{State Succession Regulations and the German Unification}

\section{By Ulrich Fastenrath}

With the unification of the two German States on Oct. 3, 1990, the German Democratic Republic (GDR) was incorporated into the Federal Republic of Germany (FRG), and thus ceased to exist. As for the treaties and conventions ratified by the "old" FRG before unification, Art. 11 of the Unification Treaty, concluded by both German States on Aug. 31, 1990, generally provides for the moving frontier rule (except for agreements on the stationing of foreign armed forces); and the unified Germany maintains the membership of the "old" FRG in international organizations. On the other hand, according to Art. 12 para. 3 of the Unification Treaty, the membership of the GDR in international organizations expires, as do rights and obligations arising from multilateral treaties entered into only by the GDR (and not by the FRG), if Germany does not decide to extend these relationships with the parties of the respective treaty. As far as bilateral treaties are concerned, the 